\title{
KARST LANDFORMS IN THE SARABURI GROUP LIMESTONES, THAILAND
}

\author{
Gheorghe Ponta, Bashir Memon, James LaMoreaux
}

PELA GeoEnvironmental, 1009 23rd Avenue, Tuscaloosa, Alabama, 35401, USA, gponta@pela.com, bmemon@pela.com,jlamoreaux@pela.com

\section{Jade Julawong, Somchai Wongsawat}

Water Resource Engineering Co., Ltd., 52 Soi Ladphrao-wanghin 26, Ladphrao-wanghin Road, Ladphrao, Bangkok10230,Thailand, j_julawong97@hotmail.com,s_wongsawat@hotmail.com

\begin{abstract}
Agricultural development in the Saraburi Province of Central Thailand has increased the demand for groundwater resources. Hydrogeological investigations have been undertaken by Department of Groundwater Resources (DGR) to identify potential zones of groundwater in the karstified limestone of the Saraburi group.

The area is located $120 \mathrm{~km}$ north of Bangkok between the cities of Saraburi and Pak Chong in the south, Lopburi to the west, Chai Badan and Nong Pong to the north, and Nakhon Ratchasima to the east. It covers the following districts: Amphoe Pack Chong, Nakhon Ratchasima Province; Amphoe Muang Muak Lek, Khangnoi, Phaputabat, Wong Muang and Chalormphrakiat in Saraburi Province; and Amphoe Moung, Lamsonthi, Phatananikom, Thaluang and Chaibadan in Lopburi Province (Figure 1).
\end{abstract}

The topography is characterized by mountain ranges, karstic plateaus, and rolling hills of low to medium relief, with low lands in between. The mountainous ridge elevation reaches over $800 \mathrm{~m}$ above sea level (ASL), karstic plateaus are developed between 300 and $500 \mathrm{~m}$ ASL, and the low lands are at about $100 \mathrm{~m}$ ASL. In the karstic plateaus and mountains areas, springs, caves, and dry stream beds exist. In dry periods, some streams in low land areas are dry, but the large rivers continue flowing.

Tropical climate (Monsoon type) with two distinct seasons is characteristic of this area. The dry season begins in October and ends in May, followed by a monsoon season between June and September. Annual rainfall ranges between 1,500 and $2,000 \mathrm{~mm}$ and temperature ranges between $20.0^{\circ} \mathrm{C}$ and $40.7^{\circ} \mathrm{C}$.
The area is underlain by the limestone of the Saraburi Group of Permian age. The limestone is exposed as a chain of hills, ridges, and occasionally as mounds which create classic 'tower karst' scenery.

The rainforests, excessive rainfall and widely variable climatic conditions caused a karst landscape and caveforming environment to develop, with streams draining into the limestones from mountain catchments. In this area, the mature karst is locally fringed by tall cliffs that overlook valleys and closed basins. The area underlain by limestone is extensive and rainfall is abundant. Therefore karstification potential exceeds 200

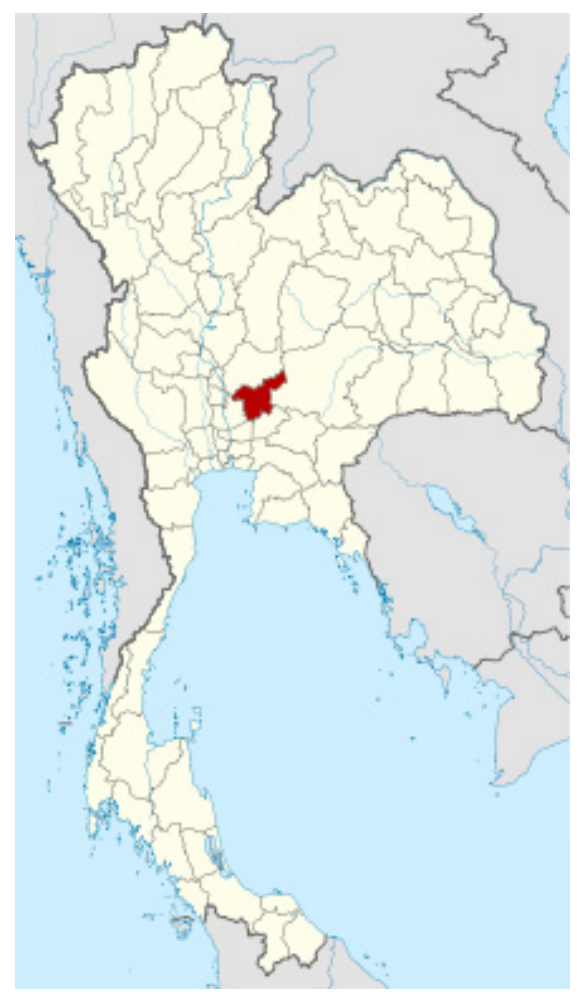

Figure 1. Saraburi Province of Thailand (shown in red). 
m vertically. Exokarst landforms are well represented. Various types of karrens, tsingi, small- to medium- sized sinkholes, sinking streams, and closed depressions were identified during site investigation.

A dye study performed in October 2012 indicated the hydraulic connection between a sinking stream and Tham Lumphini Suan Hin Spring, and a water supply well (Well 114) located 300 meters southwest of the spring. Based on the dye study, the protection area for the Well 114 and the spring also includes the closed depressions.

\section{Introduction}

Development of land in the Saraburi Province of Central Thailand has increased the demand for groundwater resources. Hydrogeological investigations have been undertaken to determine potential zones of significant accumulation of groundwater in karstified limestone aquifer of Saraburi Group for exploitation.

The area is located $120 \mathrm{~km}$ North of Bangkok between the cities of Saraburi and Pat Chong in the south, Lopburi to the west, Chai Badan and Nong Pong to the north, and Nakhon Ratchasima to the east. It covers the following districts: Amphoe Pack Chong, Nakhon Ratchasima Province; Amphoe Muang Muak Lek, Khangnoi, Phaputabat, Wong Muang and Chalormphrakiat in Saraburi Province; and Amphoe Moung, Lamsonthi, Phatananikom, Thaluang and Chaibadan in Lopburi Province.

The topography is characterized by mountain ranges, karstic plateaus, and rolling hills of low to medium relief, with low lands in between. The mountainous ridge elevation can reach over $800 \mathrm{~m}$ above sea level (ASL), karstic plateaus are developed between 300 and $500 \mathrm{~m}$ ASL, and the low lands are at about $100 \mathrm{~m}$ ASL. In the karstic plateaus and mountains areas, springs, caves, and dry streams exists. In dry periods, some streams in low land areas are dry, but the large rivers continue flowing.

Tropical climate (monsoon type) with two distinct seasons is characteristic of the project area. The dry season begins in October and ends in May, followed by a rainy season between June and September. Annual rainfall ranges between 1,500 and $2,000 \mathrm{~mm}$ and temperature ranges between $20.0^{\circ} \mathrm{C}$ and $40.7^{\circ} \mathrm{C}$.

\section{Geology}

The project area is underlain by the limestone of the Saraburi Group of Permian age. (Ridd et al., 2011) (Figure 2). The carbonate rocks are exposed as a chain of hills, ridges and occasionally as mounds which create classic 'tower karst' scenery.

In stratigraphic order from oldest to youngest, the rock units are the: Phu Phe, Khao Khwang, Nong Pong, Pang Asok, Khao Khad and Sap Bon formations.

Phu Phe Formation (Lower Permian). The carbonate formation consists of pinkish-gray to very dark gray limestone, nodular and tabular chert bands, partly intercalated with slaty shale. Fusulinids and crinoids are present.

The Phu Phe formation is located in the central south part of the project area, and its outcrop covers approximately $68 \mathrm{~km}^{2}$ as a ridge with vertical cliffs. The Phu Phe formation is thrusted over Sap Bon and Khao Khad formations of Lower- Middle and MiddleUpper Permian Age. The Phu Phe formation outcrops $25 \mathrm{~km}$ East of Saraburi. It is divided in two sections along the Highway No.2 (Mittraphat Road) between the cities of Sap Bon and Khao Phu Phe. The Siam Cement Plant quarry is located in this formation (Figure 3), north of Highway 2.

Khao Khwang/Tak Fa Formation (Lower Permian). The formation is widely distributed in the northern part of the Saraburi area. The formation was deposited in a shallow-marine platform environment (Ridd et al., 2011). From the border between Nakhon Sawan and Lop Buri provinces (the Tak Fa-Ban Mi area) to southern Phetchabun Province (the Nong Phai area), Nakornsri (1976, 1981) established the Tak Fa Formation which is mainly carbonates in the Saraburi Group.

The Khao Khwang/Tak Fa formation of Lower Permian Age is located in the northern part of the project area. The outcrop area is approximately $650 \mathrm{~km}^{2}$. It is a karstic plateau with rolling hills of low to medium relief, which continue north with a narrow strip about $25 \mathrm{~km}$ long and 4 to $1 \mathrm{~km}$ wide $\left(\sim 100 \mathrm{~km}^{2}\right.$ - Tak Fa Formation) ridge with vertical cliff and 23 dry-hillside caves. In the latest geological publications/maps the narrow limestone strip belongs to the Tak Fa Formation (Amphoe Ban Mi geological map 1:250,000). 


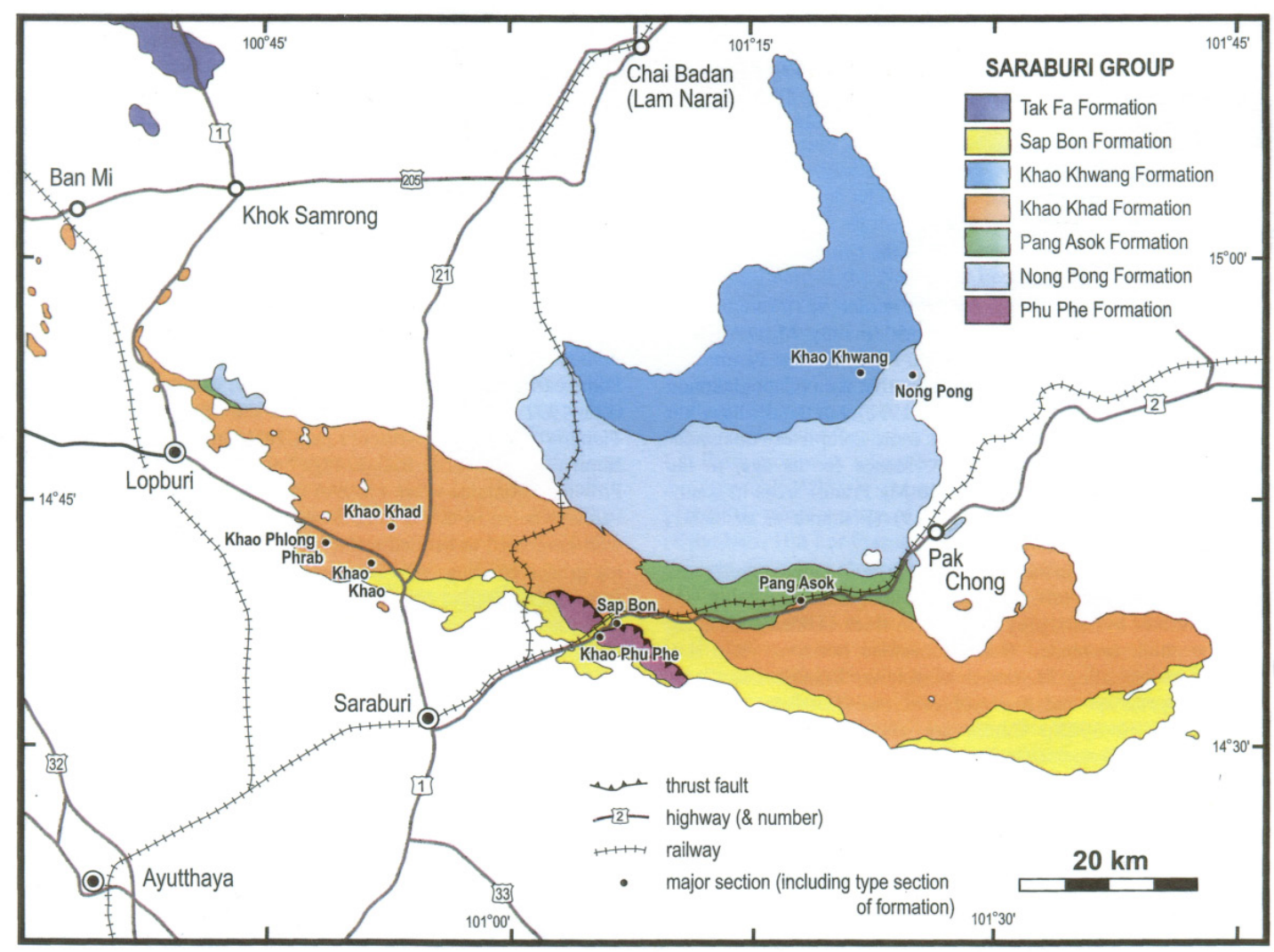

Figure 2. Geological Map of the Project Area (from Ridd et al., 2017 ).

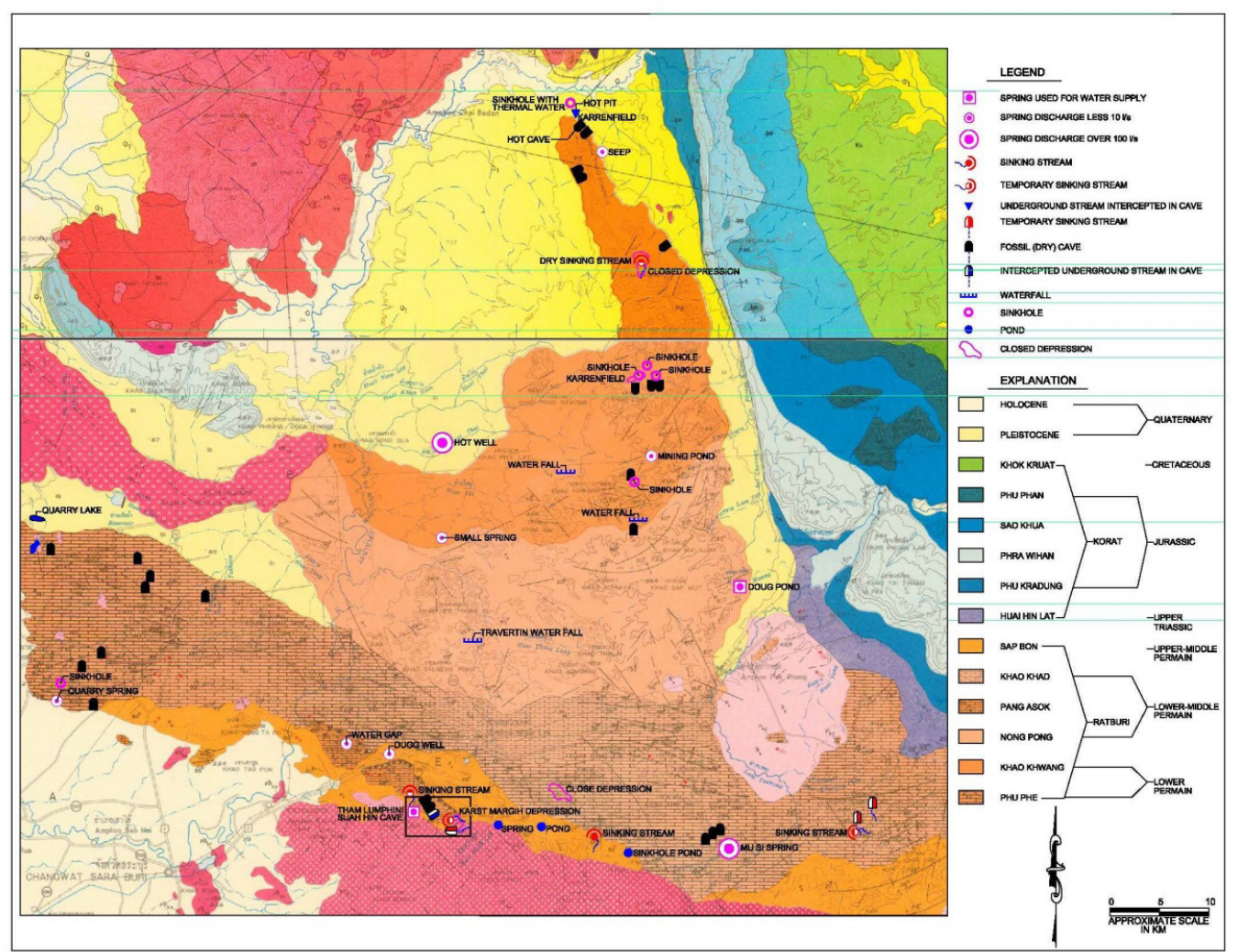

Figure 3. Geological map with location of karst features. 
Nong Pong Formation (Lower-Middle Permian). The Nong Pong Formation is dominated by intercalations of laminated thin-to-thick-bedded shale and thin-bedded limestone with locally developed chert. It occurs widely in the central part of the Saraburi area and it is approximately $670 \mathrm{~m}$ thick (Ridd et al., 2011).

The Nong Pong formation is located in the central part of the project area. The area of this outcrop is approximately $700 \mathrm{~km}^{2}$. It is a karstic plateau with rolling hills of low to medium relief.

Pang Asok Formation (Lower-Middle Permian). This siliciclastic dominated unit in the Saraburi Group crops out south of the Nong Pong Formation. It is approximately $360 \mathrm{~m}$ thick, and consists of interbedded brownish-grey to greenish-grey shale to slaty shale with local sandstone lenses (Ridd et al., 2011).

Khao Khad Formation (Lower-Middle Permian). This unit is up to $1800 \mathrm{~m}$ thick and consists of mainly thinto very thick-bedded limestone with chert nodules and locally interbedded argillite, dolomitic shale, siltstone, sandstone and conglomerate. It is distributed extensively in an almost WNW-ESE direction in the Saraburi area. (Ridd et al., 2011).

The Khao Khad formation of Lower-Middle Permian age is located in the south part of the project area. It outcrops as a limestone strip/band oriented NW- SE, $125 \mathrm{~km}$ long and $15 \mathrm{~km}$ wide. The area of outcrop is approximately $1,875 \mathrm{~km}^{2}$. It is a karstic plateau with rolling hills of high relief and some cliffs and ridges.

Sap Bon Formation (Middle-Upper Permian). This is the uppermost unit of the Saraburi Group. The Sap Bon Formation consists of pale-brown to pale-green shale and sandstone interbedded with grey to darkgrey limestone with chert nodules in the upper part. It crops out along the southern margin of the Saraburi Group. Siliciclastic rocks are partly affected by contact metamorphism and altered into slate, phyllite and schist (Ridd et al., 2011).

The Saraburi Group is part of the Indochina tectonosedimentary domain. After the latest Carboniferous, the Khao Khwang platform was developed in the project area. These units are mostly folded, fractured, and faulted across the study area.

\section{Hydrogeology}

The availability of ground water in karst aquifer system of the Saraburi Group of Permian age varies widely due to complex geology. This aquifer system has an extensive subsurface network of interconnected joints, fractures, and dissolution/solution cavities as observed in the field during the investigation. These interconnected fractures serve as conduits, leading water from the top of the mountains/karstic plateau to springs. The limestone aquifer system of the Saraburi

Group serve as a major source of groundwater for domestic, industrial, and agriculture uses. At the interface of noncalcareous formations with karstic formations, streams are sinking underground to discharge to spring(s) and cave(s). The availability of water varies during two distinct seasons. During the dry season (October to May) the flow of the springs and rivers/streams diminishes substantially. In the mountains area all the sinking streams were dry. During our field visits in December 2011, 11 springs, one perennial sinking stream, and one perennial cave stream were identified. A network of manmade ponds and lakes has been developed to collect and store surface runoff and the rain water during the wet season. A major portion of the water from the open ponds and lakes is lost due to the high rate of evaporation. Air temperatures are above $+30^{\circ} \mathrm{C}$ for most of the time.

During the rainy season (June to September) flooding occurs periodically, most of the annual rainfall of 1,500 to $2,000 \mathrm{~mm}$ has been recorded in this time frame.

\section{Karst Landforms}

The karst landforms had been developed by widely variable climate conditions during geologic times. The karstification process is ongoing in the area because of the excessive rainfall and rainforest conditions. In the project area, the mature karst is occasionally fringed by tall cliffs that overlook valleys and closed basins. The area underlain by limestone is extensive. Rainfall is abundant and the karst's vertical potential exceeds $200 \mathrm{~m}$ (field observations). Exokarst landforms are well represented. Various types of karren, tsingi, smallto medium- sized sinkholes, sinking streams, and closed depressions are present. 


\section{Karrenfields}

Karrenfields were identified across the area, the most extensive ones being located in the north of the study area (Figure 4). The second one is two kilometer east of $\mathrm{Mu}$ Si Spring, next to a temporary sinking stream (Figure 5).

\section{Tsingi}

Tsingi is characterized by vertical rock blades fretted sharp by dissolution (Figure 6). This feature was found on the limestone hills surrounding the karst margin depression, in the central-south section of the project area.

\section{Closed Depressions}

The following types of closed depressions were identified in the study area:

\section{Rain pits}

Rain pits $(1 \mathrm{~cm}$ to about $3 \mathrm{~cm}$ in size) in the Vicinity of the Waterfall in Khao Khwang Limestone- Huai Nam Sap River (Figure 7).

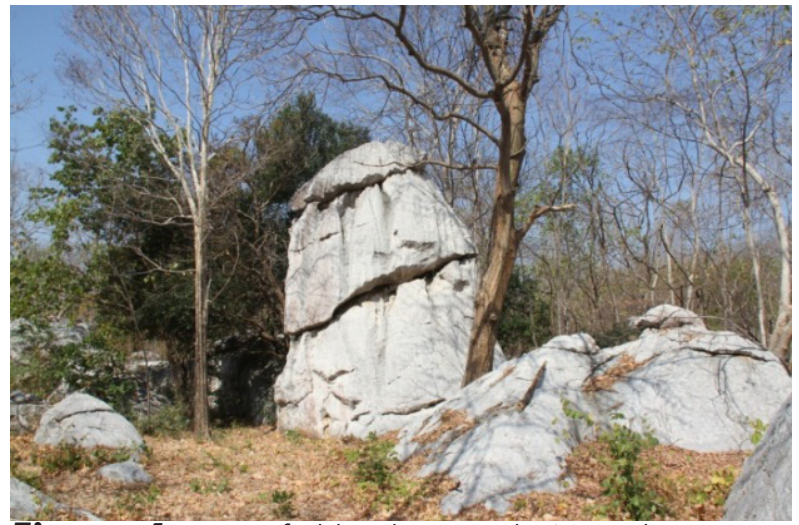

Figure 4. Karrenfield with Pinnacle (Wat Tham Phrommaloc).

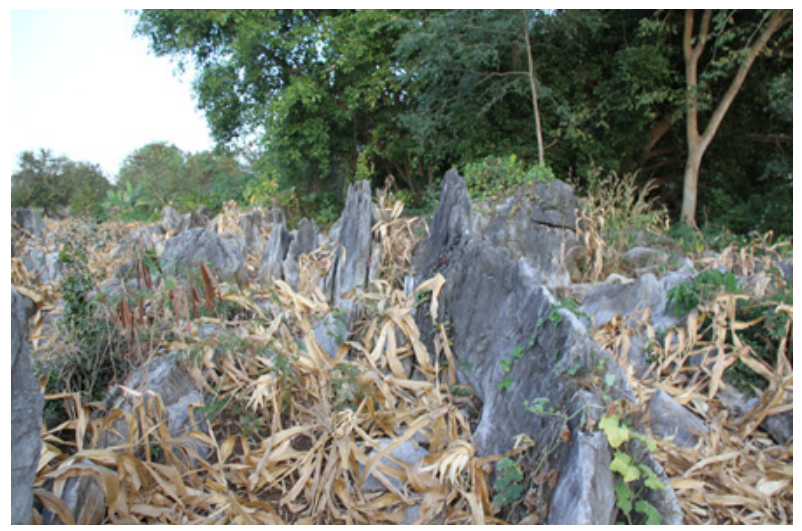

Figure 5. Karren Field - Two km East of Mu Si Spring (Ban Khao Chan Hom).

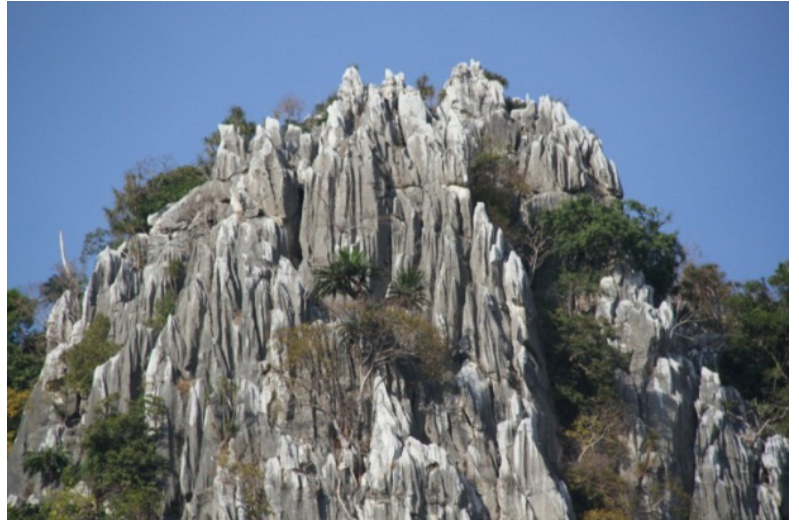

Figure 6. Tsingi in the Karst Margin Depression (Recharge area of Tham Lumphini Spring).

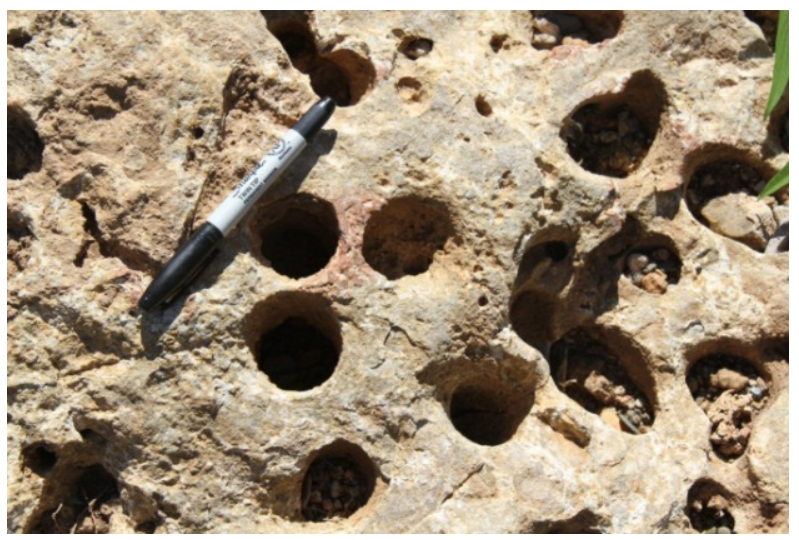

Figure 7. Rain Pits in the Vicinity of the Waterfall in Khao Khwang Limestone- Huai Nam Sap River.

Kamenitza

Kamenitza in the vicinity of Quarry Spring - Khao Khad limestone (Figure 8).

Sinkholes (Dolines)

Several sinkholes were identified in the northeastern section of the project area. One of the sinkholes was holding thermal water at $37.10^{\circ} \mathrm{C}$ during field visit in December 2011. The sinkhole is about $10 \mathrm{~m}$ in diameter (Figure 9).

\section{Closed depressions}

Three large closed depressions and one karst margin depression were identified in the study area. One closed depression oriented NE-SW is located in the vicinity of Ban Khao Takhaeng village, about $15 \mathrm{~km}$ south of the area of geothermal anomaly (Figure 10). It is over $2 \mathrm{~km}$ long and $1 \mathrm{~km}$ wide. A swallet is located at the north end of the depression. During the rainy season, the disappearing stream recharges a temporary karst spring at the base of limestone massif, generating a karst system with temporary flow. 


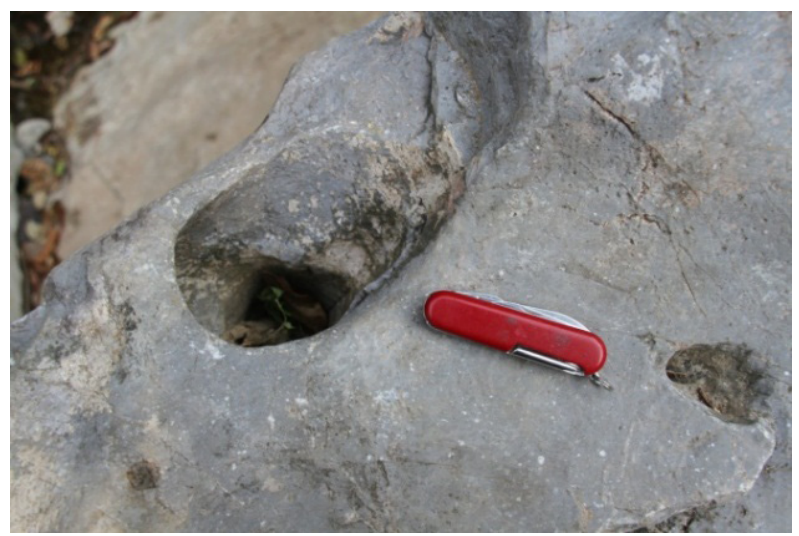

Figure 8. Kamenitza in the vicinity of Quarry Spring - Khao Khad limestone.

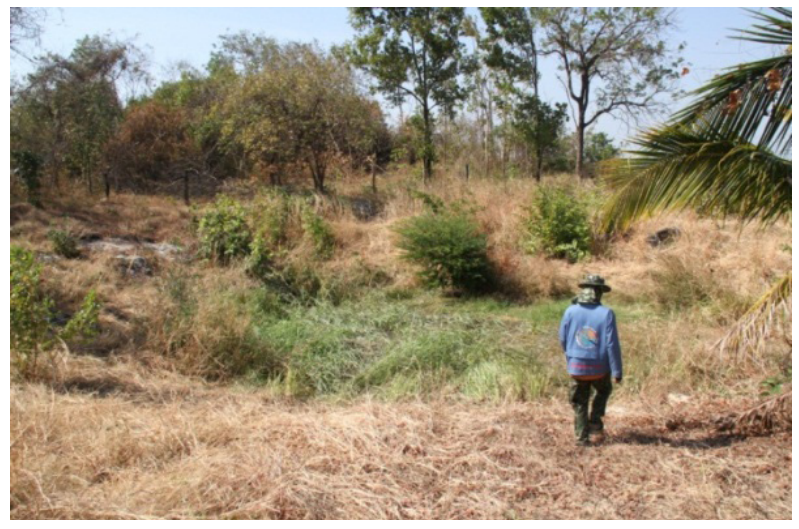

Figure 9. Sinkhole with Thermal Water in Vicinity of Wat Tham Phrommaloc Temple.

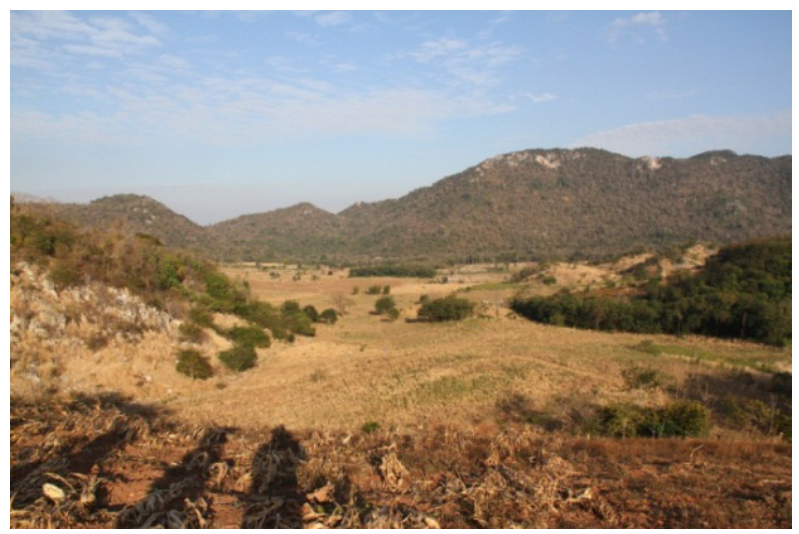

Figure 10. Closed Depression in the vicinity of Ban Khao Takhaeng Village.

A karst margin depression exists in the recharge area of the Tham Lumphini Suan Hin cave system, which is discussed in Dye Study section.

A third location with closed depressions is situated between the villages of Ban Khao Phra and Ban Khao Loi, about $20 \mathrm{~km}$ east of Mu Si Spring (Figure 3).

\section{Springs}

In the study area 11 perennial springs were identified (Figure 3). The estimated flow ranges between 0.1 to $400 \mathrm{l} / \mathrm{s}$. The largest spring is the "Hot Well" located in the northern section of the project area, in the villages of Ban Nong Nun - Wat Nam Sut (Figure 11). The estimated flow in December 2011 was about 400 1/s. Based on the geological map, the spring is located in Pleistocene deposit that lie on the top of the Khao Khvang limestone of Lower Permian Age.

$\mathrm{Mu}$ Si Spring is located in the south-central part of the project area, in Khao Khad limestone, with a base flow estimated in December 2011 at 150 1/s. The recharge area of both springs (Hot Well and Mu Si Spring) has not been defined (Figure 12).

The Dug Pond and the Tham Lumphini Suan springs have an estimated flow ranging between 15 and 25 1/s. Both springs are used locally for public water supply. The other springs have an estimated flows ranging between 0.1 and $2.0 \mathrm{l} / \mathrm{s}$.

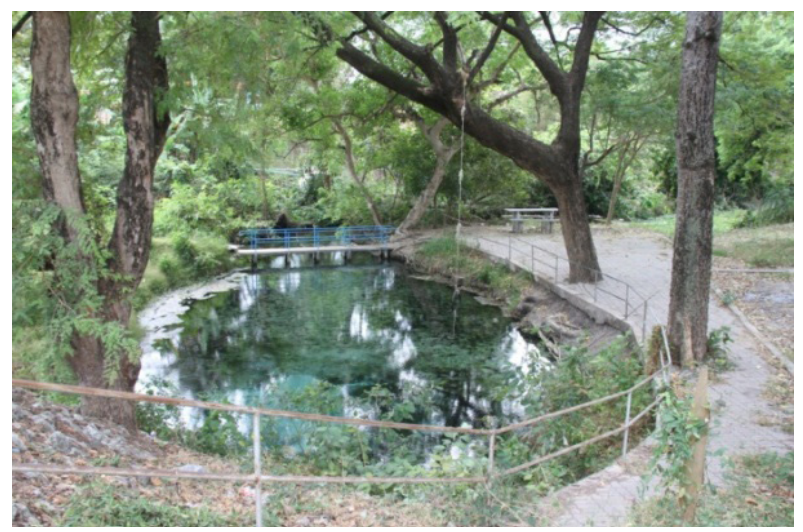

Figure 11. Hot Well (Bat Nong Nun - Wat Nam Sut).

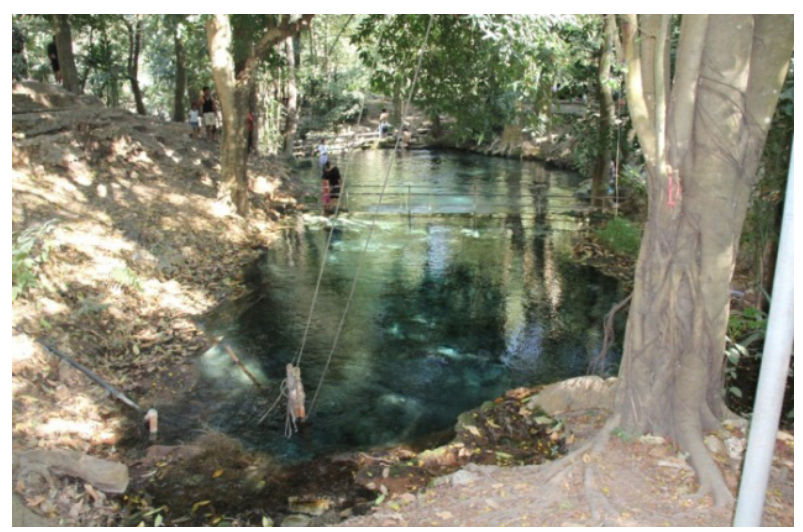

Figure 12. Mu Si Spring. 


\section{Dye Study}

To characterize groundwater resources in the Saraburi province, a dye study was performed in October 2012.

The Tham Lumphini Suan spring is one of three major springs in the study area, with an estimated flow ranging between 15 and $125 \mathrm{l} / \mathrm{s}$ (during the dye study the flow was $106 \mathrm{l} / \mathrm{s})$. A karst margin depression $(1.5 \mathrm{~km}$ long and $1 \mathrm{~km}$ wide) is located in the recharge area of the Tham Lumphini Suan Hin cave system. The south side of the depression is bounded by igneous rock and the north side by a limestone ridge. This limestone ridge is the boundary between the karst margin depression and the closed depression developed along a parallel stream, both being part of the Tham Lumphini Suan Hin cave/resurgence watershed. The karst margin depression ends in a temporary swallet/cave, which in the rainy season, based on the size of the stream bed accommodates a flow up to $1,000 \mathrm{l} / \mathrm{s}$. The cave formed by the sinking stream is linked to the Tham Lumphini Suan Hin cave system (Figure 13).

The primary focus of the dye study was to illustrate the potential hydraulic connectivity of the sinking stream to Tham Lumphini Suan Hin Spring.

Some potential sources for background fluorescence are detergents, bathroom cleaners, pigments for inks and dyes, antifreeze, industrial wastes, naturally-occurring mineral fluorescence, and residual dye from previous studies. Therefore, natural or man-made background fluorescence of the ground water was monitored prior to injection of the dye (background concentration).

A passive dye detector (charcoal bag) was placed at the Tham Lumphini Suan Hin Spring, seven days prior to injection of the dye at the sinking stream. The first charcoal bag for the background portion of the dye was installed on October 6, 2012. The detector was removed for evaluation for background readings one day prior to injection of the dye. A well located in the vicinity of the temple (Well 114) and the right side tributary located downstream the Tham Lumphini Suan Hin spring were monitored during the dye study. No dye was detected in the background charcoal bags. However in the water samples collected at the Tham Lumphini Suan spring before the injection of the dye (background samples), dye was identified as $0.212 \mathrm{ug} / 1$ and $0.148 \mathrm{ug} / \mathrm{l}$, respectively. The average of those concentrations 0.18 ug/l was deducted from all the concentrations identified in the water samples collected during the dye study, as a background adjustment.

On October 13, 2012 at 11:00 AM, 200 grams of Uranine (powdered Uranine $40 \%$ concentration mixed with a total of 5 liters of water) were injected at the sinking stream. Temperature $\left(24.8^{\circ} \mathrm{C}\right), \mathrm{pH}(8.05)$, specific conductance ( $225.7 \mathrm{us})$, and salinity ( $0.1 \mathrm{ppt})$ were determined at the time of dye injection.

During the dye study, charcoal bags were installed and water samples were collected at the spring, 687 $\mathrm{m}$ away from the sinking stream. Also a charcoal bag was installed about 300 meters downstream of Tham Lumphini Suan Hin Spring, in the right site tributary.

The Uranine was detected in the elutant from all 17 charcoal bags installed and recovered during the dye study at Tham Lumphini Suan Hin Spring. The first arrival of the dye was recorded 20 hours after injection, with the peak dye concentration $(6.67 \mathrm{ug} / \mathrm{l})$ being detected on October 15, 2012, 51 hours after injection (flow velocity $35 \mathrm{~m} /$ hours). The location of dye injection and monitoring points (spring and Well 114) are shown in Figure 13. Dye detections at the spring and Well 114 are shown on Figure 14.

The peak dye concentration of elutant from charcoal bags recovered from Tham Lumphini Suan Hin spring is 989 Fluorescence Intensity Units (IU), and was detected in the charcoal bag collected 2 days (47-51 hours) after dye injection.

Well 114 (50 $\mathrm{m}$ deep) is a water supply well, located 338 meters northwest of Tham Lumphini Suan Hin Spring. Two water samples were collected during the dye study. Dye was detected in the water sample collected on October 15, 2012, 51 hours after injection (flow velocity $19 \mathrm{~m} /$ hour), at $6.60 \mathrm{ug} / 1$ (after background adjustment), which is the peak dye concentration. A second sample was collected on October 18, 2012, the dye was detected at a concentration of $0.026 \mathrm{ug} / \mathrm{l}$ (after background adjustment) (Figure 15).

These results suggest that the groundwater is rapidly traveling between the sinking stream and spring through a fracture system. The direction of ground-water movement is to the northwest. 


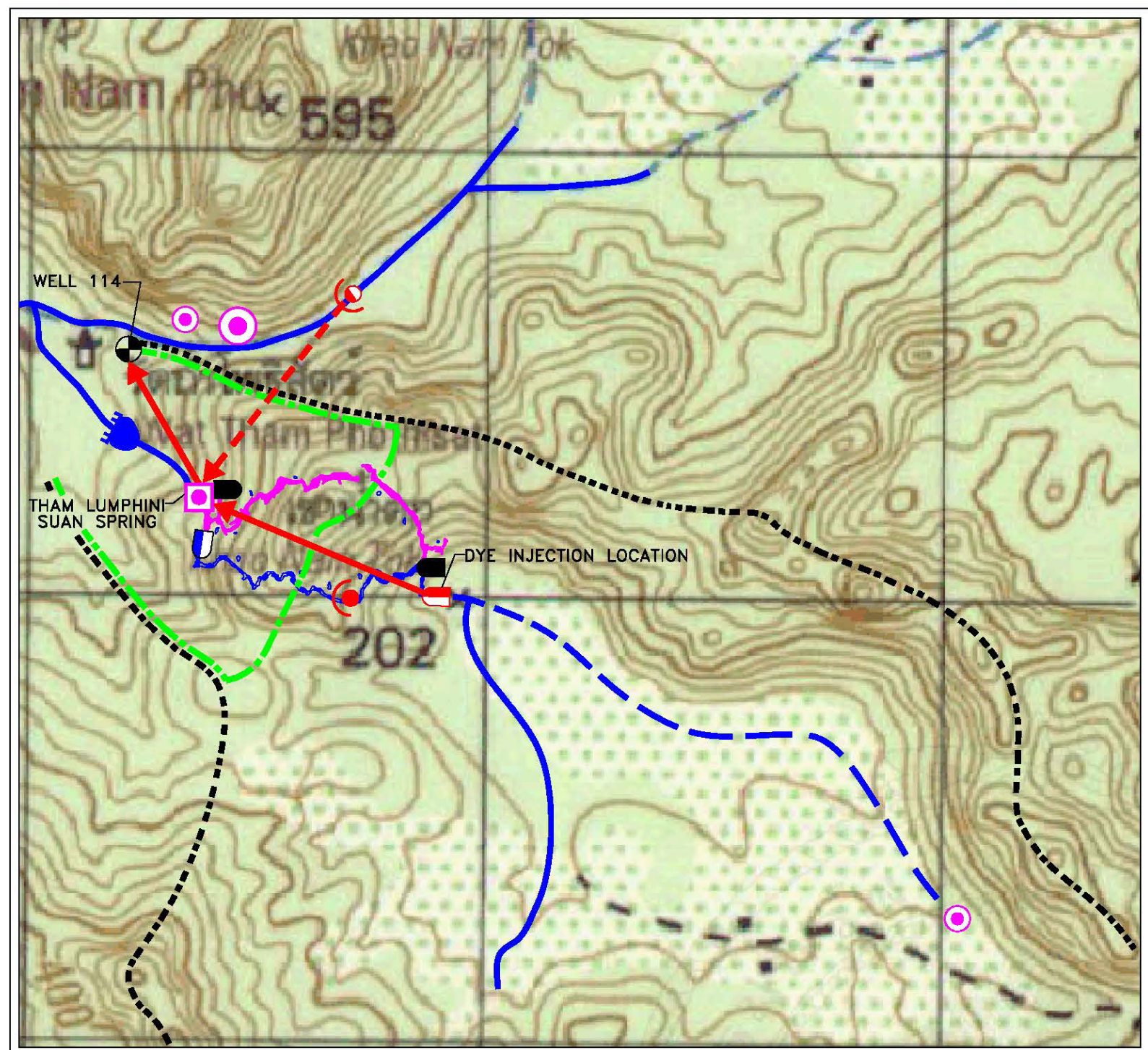

SOURCE: THAM LUMPHINI SUAN HIN CAVE SURVEYED BY THAILAND CAVE \& KARST GROUP, 1998

LEGEND

- SPRING USED FOR WATER SUPPLY (DISCHARGE OVER $100 \mathrm{l} / \mathrm{s}$ )

SPRING DISCHARGE LESS $10 \mathrm{l} / \mathrm{s}$

(-) SPRING DISCHARGE $10-100 \mathrm{l} / \mathrm{s}$

$\theta$ WELL

-D) TEMPORARY SINKING STREAM

I DRY CAVE PASSAGE

STREAM CAVE PASSAGE

CAVE TEMPORARY SINKING STREAM

FOSSIL (DRY) CAVE

0 CAVE INTERCEPT

UNDERGROUND STREAM

0

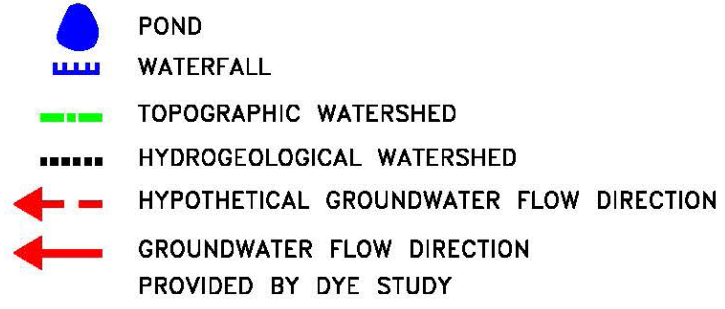
PROVIDED BY DYE STUDY APPROXIMATE SCALE IN METERS
25,000

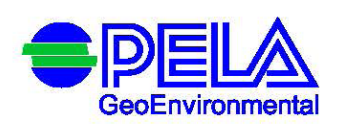

Figure 13. Topographic map showing the dye injection location and Tham Lumphini Suan Hin Spring. 


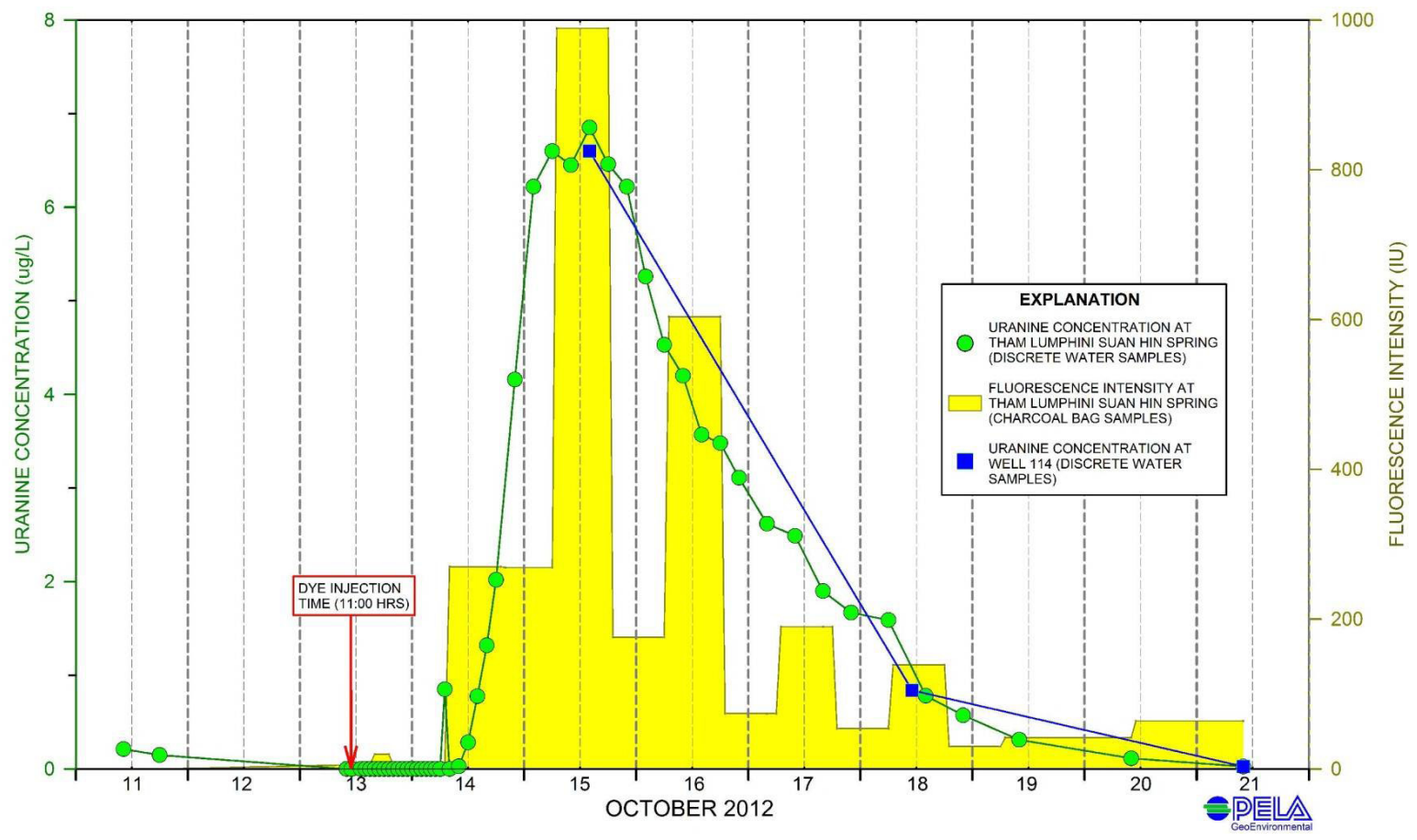

Figure 14. Breakthrough of Uranine at Tham Lumphini Suan Spring and Well 114.

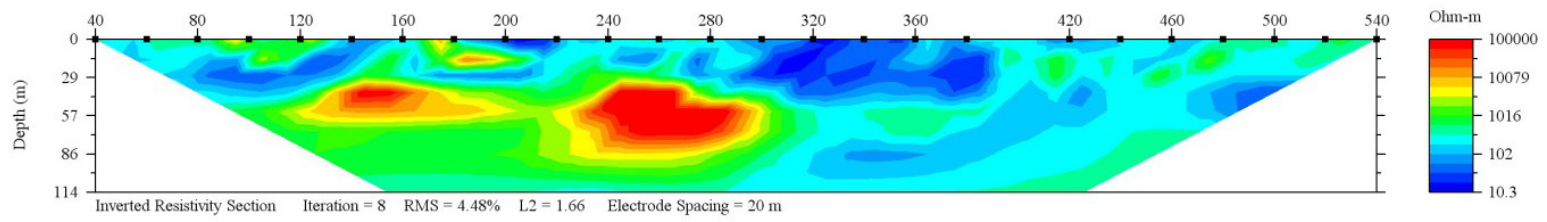

Figure 15. Interpreted DC resistivity profile.

Southeast $\leftarrow$ MMA207 $\rightarrow$ Northwest

Based on this dye study, the recharge area of The Tham Lumphini Suan Spring and Well 114 is extended to 4.5 square kilometers towards the dye input location, which also include the closed depression, west to the spring.

\section{Geophysical (Resistivity) Survey}

To identify favorable locations for groundwater exploration in the Saraburi Group karstified aquifer system and characterize groundwater resources, an extensive resistivity geophysical survey was performed.

Groundwater can exist in the pore spaces of soil or rock under saturated conditions (i.e. all of the pores, voids, and fractures are filled with water) or unsaturated conditions. It can also exist as underground rivers and lakes in karst environments. Since electricity can move more easily through water than soil or rock, the bulk electrical resistivity of the earth is highly dependent on the presence of water, as well as the salinity of the water. In general, the electrical resistivity of carbonate rock is on the order of thousands of ohm-meters.

The electrical resistivity of soil is on the order of hundreds of ohm-meters, and the electrical resistivity of groundwater is on the order of tens of ohm-meters. These ranges are general estimates, but illustrate the relative difference in electrical resistivity of earth materials.

Direct-current (DC) electrical resistivity was performed along sixty seven (67) profiles distributed throughout the Saraburi Province. Profiles were generally situated along roadsides and were located within various discharge and recharge zones throughout the Province. Data were acquired using a Supersting ${ }^{\mathrm{TM}}$ 8-channel, 56-electrode system. An electrode spacing of 20 meters $(\mathrm{m})$ was used for a total 
array length of $1100 \mathrm{~m}$. The dipole-dipole array was used so that lateral variations in electrical resistivity indicative of karst features could be resolved.

Deep (greater than $50 \mathrm{~m}$ ) low-resistivity anomalies that may be indicative of groundwater were identified. These low-resistivity anomalies were interpreted as potential locations where large amounts of groundwater accumulations, possibly associated with subsurface karst features could be exploited.

Numerous deep $(>50 \mathrm{~m})$ low-resistivity anomalies were found along various inverted resistivity profiles. These anomalies are shown in blue in all sixtyseven profiles. One profile (Figure 15) is included herein for illustration purpose. Figure 16 is geologic map showing areas of groundwater potential, with marking low $(\mathrm{L})$, moderate $(\mathrm{M})$, high $(\mathrm{H})$ and very high $(\mathrm{VH})$. These anomalies may correspond to accumulations of groundwater in karst features within the limestone. Other smaller low-resistivity features exist in the profiles indicating that there are extensive groundwater reserves in the area.

Based on the interpretation of the various datasets, the potential for recoverable groundwater was mapped on the geologic map. These zones are marked as low (L), moderate (M), high $(\mathrm{H})$ and very high (VH) (Figure 16). Zones of significant groundwater production potential exist along the edge of the Khorat Plateau. With respect to elevation there is not a strong regional correlation between elevation and groundwater potential, which suggests that the various water-bearing units throughout the region are hydraulically discontinuous, because of geologic structures. This is typical and to be expected in karst terrain due to lack of hydraulic communication between the various subsurface water bearing zones in the region.

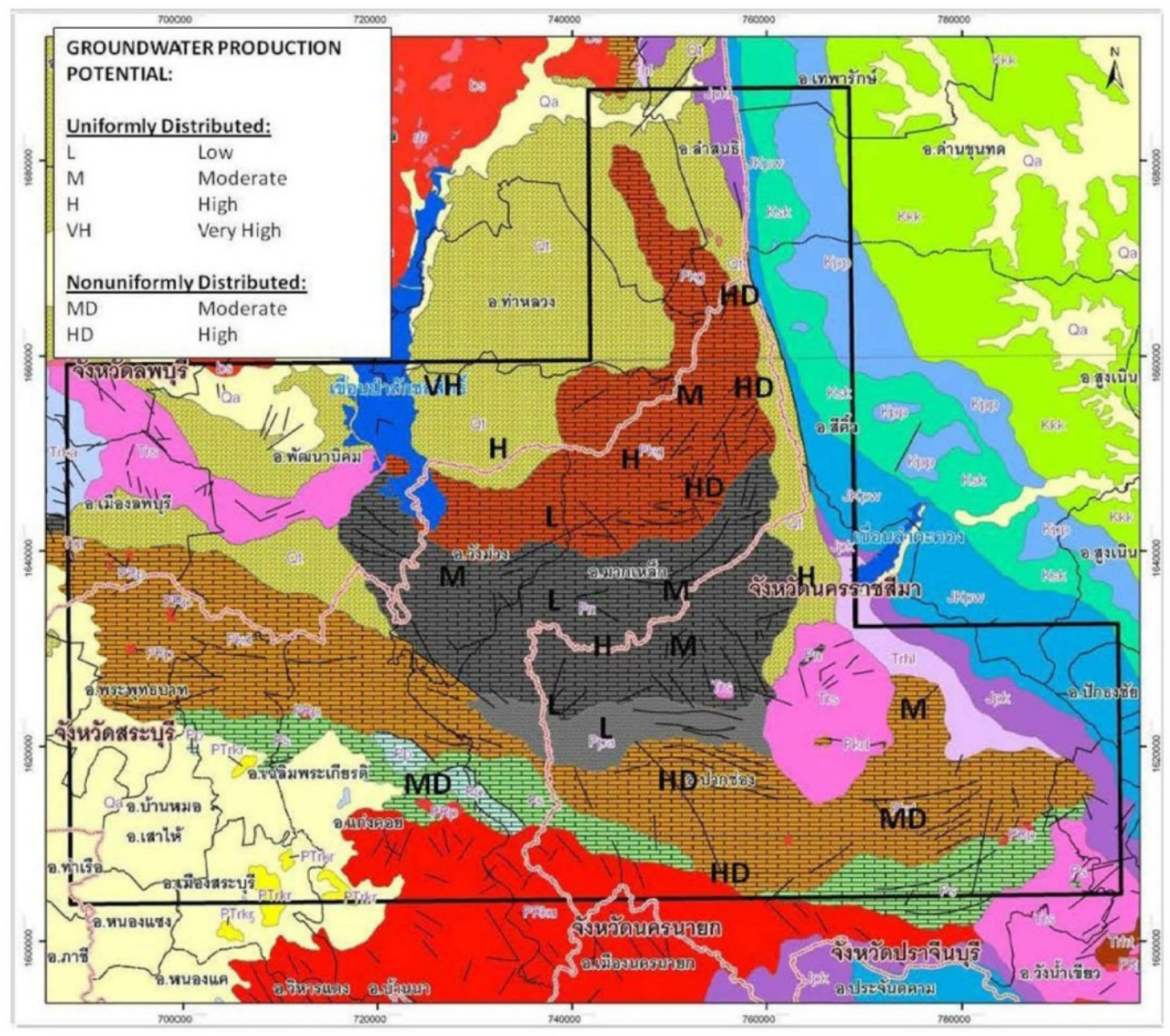

Figure 16. Geologic map of groundwater production potential. 


\section{Conclusions}

The area is underlain by the limestone of the Ratburi Group of Permian age. The carbonate rocks of the Ratburi Group exposed to the east of Chao Phraya Central Plain belong to the Saraburi Group. The limestone is exposed as a chain of hills, ridges and occasionally as mounds which create classic 'tower karst' scenery.

Exokarst landforms are well represented. Various types of karrens, tsingi, small- to medium- sized sinkholes, sinking streams, and closed depressions were identified, during site investigation.

A dye study indicated that there is hydraulic connection between a sinking stream and Tham Lumphini Suan Hin Spring, and a water supply well (Well 114) located $300 \mathrm{~m}$ southwest of the spring. Based on this dye study, the protection area for the Well 114 and the spring also includes the closed depression.

Based on the interpretation of the various geophysical datasets, the potential for recoverable groundwater was mapped on geologic map (Figure 16). These zones are marked as low (L), moderate $(\mathrm{M})$, high $(\mathrm{H})$ and very high $(\mathrm{VH})$. Zones of significant groundwater production potential exist along the edge of the Khorat Plateau. With respect to elevation there is not a strong regional correlation between elevation and groundwater potential, which suggests that the various water-bearing units throughout the region are hydraulically discontinuous, because of geologic structure. This is typical and to be expected in karst terrain due to lack of hydraulic communication between the various subsurface water bearing zones in the region.

\section{References}

Amphoe Ban Mi. 1977. [Geologic Map]. Scale 1:250,000.

Changwat Pranakhon Si Ayutthaya. 1973-1975. [Geologic Map]. Scale 1:250,000.

Dunkley JR. 1997. The Caves of Thailand-Addendum 1995-97. Sydney (AU): Speleological Research Council.

Ellis M. Caves and Caving in Thailand [Internet]. 2012. Available from: $h$ ttp://www.thailandcaves.shepton.org.uk. Nakornsri N. Amphoe Ban Mi [Geological Map]. Bangkok (Thailand): Geological Survey Division, Department of Mineral Resources; 1977. Sheet ND 47-4, Scale 1:250,000.
Nakornsri N. 1981. Geology and Mineral Resources of Amphoe Ban Mi. Geological Survey Report No. 3. Bangkok (Thailand): Department of Mineral Resources, p 1-36 (in Thai with English summary). Ridd MF, Barber AJ, Crow MJ. 2011. The Geology of Thailand. London (UK): The Geological Society of London. 
